\title{
The South America East Coast Reefer Cargo: A Diagnosis of a Competitive Market
}

\author{
Galvão Cassia Bömer ${ }^{1}$ and Robles Leo Tadeu ${ }^{2}$ \\ ${ }^{1}$ Pontifícia Universidade Catolica de Sao Paulo, Sao Paulo, Brazil \\ ${ }^{2}$ Federal University of Maranhao - UFMA, Sao Luis, Brazil \\ Correspondence should be addressed to: Galvão Cassia Bömer; cbgalvao@yahoo.com.br \\ Received date: 8 October 2013; Accepted date: 30 January 2014; Published date: 31 December 2014 \\ Copyright (C 2014. Galvão Cassia Bömer and Robles Leo Tadeu. Distributed under Creative \\ Commons CC-BY 3.0

\begin{abstract}
This paper analyses reefer cargo maritime shipping characteristics and development in South American East Coast ports. The geographical area studied goes from Punta Arenas (Chile) to Manaus (Brazil). The study main hypothesis is reefer shipping as a profitable market niche in spite of higher operation costs and a very demanding supply chain. The paper comprises three sections: the first one describes global reefer cargo transportation general characteristics; the second, reefer shipping in South American ports, focusing five main issues: (1) Cargo flows; (2) Ports infrastructure; (3) Post-Panamax vessels operation and its economies of scale; (4) Shippers and carriers' mergers and acquisitions processes and (5) Containerization process; finally, it investigates the marketing relationship between shippers and shipping liners. The exploratory study was based on technical reports and statistics analysis, and interviews with industry executives, performing a multicase study. The general conclusions indicate that South American reefer market has concluded most of its containerization process and is moving fast towards a concentrated market of players. Some experts consider that the market will keep increasing as a result of the improved quality of products and enhancing cold logistics services provision in spite of the international crisis, due to emergent markets buying and more demanding clients.
\end{abstract}

Keywords: Reefer cargo; South America; logistics services providing, cold logistics.

\section{Introduction to the Perishable Goods world}

The transport of perishable goods under refrigeration is relatively new in shipping history, and refrigeration was not popularized before the beginning of the Nineteenth Century, in spite of the fact that sea transport for goods is dated from over 5,000 years. Foodstuff transportation between regions was possible only in short distance and perishable goods were not even considered transportable. According to Waals (2010), "To bypass this problem, in 1879 the first ice-making machinery was 
installed onto a vessel, for the transport of chilled meat."

It can be considered that the elements for a consistent refrigerated cargo trade development only came after World War II ending, as merchant ships could cross the Oceans and deep sea trades recover its frequent and regular basis; European countries were all under reconstruction and needed to be supplied (foodstuff inclusive); South American countries have had all production conditions to start a significant export trade of products like meat and fresh fruits.

Nowadays, according to the Brazilian Poultry Raising (União Brasileira de Avicultura - UBABEF) ${ }^{1}$ in 2010 Brazil has exported 5.7 millions of tons of meat, with 3.9 million referred to as poultry ${ }^{2}$. Also in 2010, Argentina has exported 395,000 tons of fresh fruit only from Patagonia area $^{3}$, mainly apples and pears, confirming the importance of these two countries in the perishable trade.

This study aims to understand the characteristics and recent development of reefer cargo international sea transport in South American East Coast, including Brazilian, Argentinean, Uruguayan ports and also Paraguayan cargo loaded on transhipment operation. The paper is divided in three sections. The first one describes global reefer cargo transportation general characteristics, i.e., the system comprised by reefer container itself, goods packaging, plugging devices and facilities in port terminals and ships with proper equipment to carry reefer containers. The theory background is based upon the analysis of competitive and structural recent changes in the industry due to a concentration process. The second section reports recent development in five main market aspects: (1) Cargo flows; (2) Ports infrastructure; (3) Post-Panamax vessels operation and consequent economies of scale; (4) Shippers and carriers' mergers and acquisitions processes and (5) Containerization process. Finally, third section analyses the relationship between shippers and shipping liners and the recent merging process impacts in the competitive environment.

\section{Global reefer cargo transportation market}

It is important to quote the technical definition of perishable cargo: "Article that can lose its usefulness and value if not appropriately stored or transported or if it not utilized within certain period". (Business Dictionary, 2011) This paper focuses on perishable cargo, not only sensitive to time but also with a clear need of temperature controlling 4 .

Other settings may also be required like the humidity to prevent dehydration and ventilation to remove ethylene gas (and its effect on fruits' ripening). The temperature control represents a determinant factor for successful refrigerated goods transportation, in a way that temperature control responsibility is a constant carriers and shipping lines concern as temperature diversions are one of the main reasons for cargo damages and claims (MMS, 2006). In this sense, specialists ${ }^{5}$ also say that product practical shelf life will be determined by three key factors: cargo preparation, preservation and packaging and the transit time and temperature composition. (Maersk, 2006)

So far, there is no technology available to reverse goods' deterioration caused by temperature effects. Hence the temperature control must be done all through the supply chain, from origin to destination. Any error or miss in temperature control during transportation could have consequences for the remaining cold chain links. This actually explains why perishable goods are almost a synonym of refrigerated cargo or just reefer cargo, as it is usually known in the industry. The paper is focused on foodstuff segment due to its major share in the South American East Coast trades, as further is demonstrated.

Reefer cargo transportation, despite its higher costs and risks (in comparison with general dry cargo), can be considered as a maritime container market worth niche with a remarkable development in the last 
years, following the several changes that occurred in the international logistics of perishable goods. In fact, shipping this kind of goods became cheaper and trustable and supermarkets and retailers can keep products' range less seasonal, inducing new consumers' habits of foodstuff.
The historic background demonstrates that technological development could not only make shipping industry more diversified, but the market itself expanded. Figure 1 shows in a nutshell the main route directions of perishable goods: very much concentrated in the South-North trade.

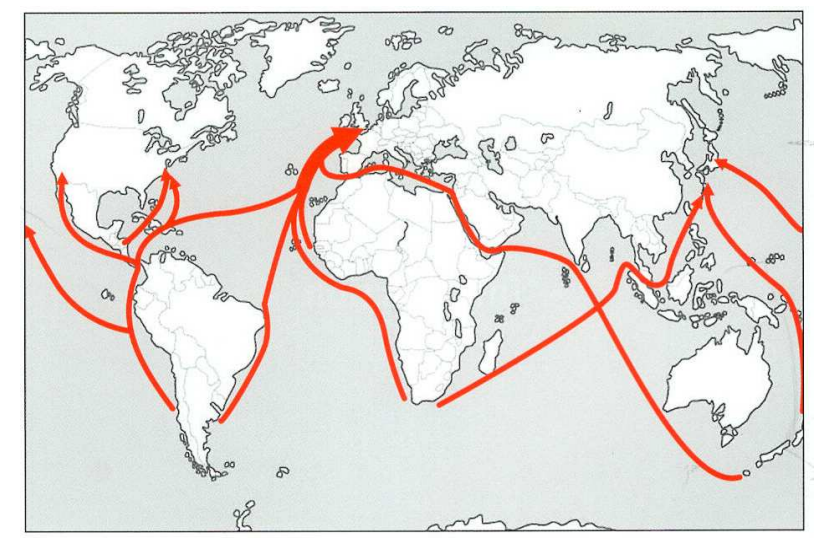

Figure1: Perishable Food trade main routes

Source: De Haan (2005).

\section{The Fleet}

Nowadays, the reefer fleet can be divided in two main groups: full reefer vessels and reefer containers. The reefer container is a typical sea-freight container, i.e., a metal box with standard measures in order to secure international standardization and operation on vessels, terminals and Lorries (chassis), and it is equipped with special devices to control inside temperatures.

The sea-container appeared in 1956 created by Malcon McLean and its measure standardization a little later facilitating cargo consolidation and vessel operation ${ }^{6}$. Containers have been largely used in reefer market following mechanical and chemical refrigeration systems' development as portable units. Stopford (2009)
The combination of container, refrigeration portable systems (adapted to containers composing reefer containers) and the development of liner services ${ }^{7}$ gave the required elements for a rapid and consistent trade of reefer containers. The first reefer container liner service was established in 1971 from Australia and New Zealand to U.S. A. West Coast and further during the 1970s to Europe. (Hamburg Süd, 2010)

The containerized fleet capacity has surpassed the full reefer capacity (see Figure 2) due to its advantages as: suitability to smaller lots of cargo; unbroken cold chain (as mentioned before, a key factor for success in refrigerated transport); minimum; intermediate storage elimination and possible door-to-door deliveries (as the container can be carried by lorry to any place). 


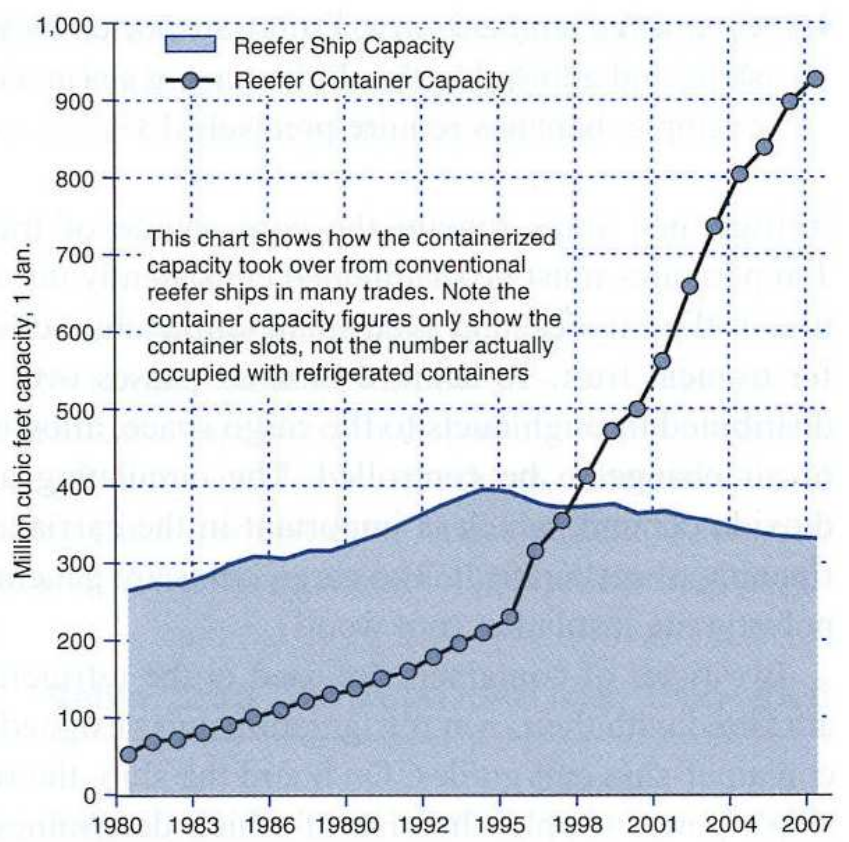

Figure 2: Reefer fleet and the reefer container capacities 1980-2007

Source: Clarkson Research Reefer and Container Registers in Stopford (2009)

For certain trades, specifically due to volumes and port pairs involved, the full reefer ships present advantages over the container such as: faster transit time, due to the much reduced number of port calls and direct transhipment from vessel to vessel (more relevant in the case of fish catching). In this regard, it is relevant to quote the information provided by Dynamar Consultant (2010) which clearly shows that since late 1990's and all through the following decade there was an increasing number of reefer plugs in a higher proportion that the TEU nominal capacity has increased in the same period. This means that the reefer plug capacity ratio per vessel TEU capacity has increade from $9 \%$ in ealy 1990's to $15 \%$ in 2010.

As demonstrated, full reefer vessels' capacity is decreasing, as every year larger vessels go on scrapping as new vessels are taken place to service. The direct consequence of this process is cargo containerization. Table 1 shows the forecast until 2015, as presented by Drewry (2010).

Table 1: Estimated perishable reefer cargo modal split 2009-2015

\begin{tabular}{|l|c|c|c|c|c|c|c|c|}
\hline \multirow{2}{*}{ Commodity } & \multicolumn{2}{|c|}{2009} & \multicolumn{2}{c|}{2010} & \multicolumn{2}{c|}{2012} & \multicolumn{2}{c|}{2015} \\
& Non-container & Container & Non-container & Container & Non-container & Container & Non-container & Container \\
\hline Bananas & $67,1 \%$ & $32,9 \%$ & $67,0 \%$ & $33,0 \%$ & $62,0 \%$ & $38,0 \%$ & $53,0 \%$ & $47,0 \%$ \\
Citrus & $61,4 \%$ & $38,6 \%$ & $53,0 \%$ & $47,0 \%$ & $45,0 \%$ & $55,0 \%$ & $32,0 \%$ & $68,0 \%$ \\
Deciduous & $46,8 \%$ & $53,2 \%$ & $41,0 \%$ & $59,0 \%$ & $35,0 \%$ & $65,0 \%$ & $28,0 \%$ & $72,0 \%$ \\
Exotics & $41,4 \%$ & $58,6 \%$ & $38,0 \%$ & $62,0 \%$ & $32,0 \%$ & $68,0 \%$ & $21,0 \%$ & $79,0 \%$ \\
Fish/Seafood & $50,0 \%$ & $50,0 \%$ & $44,0 \%$ & $56,0 \%$ & $38,0 \%$ & $62,0 \%$ & $31,0 \%$ & $69,0 \%$ \\
Meat'Poultry & $27,1 \%$ & $72,9 \%$ & $23,0 \%$ & $77,0 \%$ & $19,0 \%$ & $81,0 \%$ & $15,0 \%$ & $85,0 \%$ \\
Dairy & $5,6 \%$ & $94,4 \%$ & $7,0 \%$ & $93,0 \%$ & $5,0 \%$ & $95,0 \%$ & $4,0 \%$ & $96,0 \%$ \\
Other & $\mathbf{7 , 1} \%$ & $92,9 \%$ & $7,0 \%$ & $93,0 \%$ & $6,0 \%$ & $94,0 \%$ & $4,0 \%$ & $96,0 \%$ \\
\hline Total & $\mathbf{3 8 , 2 \%}$ & $\mathbf{6 1 , 8 \%}$ & $\mathbf{3 5 , 1} \%$ & $\mathbf{6 4 , 9 \%}$ & $\mathbf{3 0 , 0} \%$ & $\mathbf{7 0 , 0} \%$ & $\mathbf{2 4 , 3 \%}$ & $\mathbf{7 5 , 7 \%}$ \\
\hline
\end{tabular}

Source: Authors' elaboration based on Drewry research \& Sextant Consultancy (2010) 
Unless nothing changes in this trend, one could conclude that the containerization process is moving to a complete substitution of traditional full reefer vessels. How long this process will last, it will depend on how full reefers can survive or re-invent their features, which can be considered very difficult considering the trades' trend as detailed in the next section.

\section{The Cargo}

In the last 10 years, perishable cargo reefer volume corresponds to over $50 \%$ of the total seaborne volume, as authors analysed from Drewry Reefer Shipping Market 2010/11; FAO database 2005, GTIS, 2006 and Sextant Consultancy. This information alone gives also an important hint on future studies of reefer cargo transported by other transport modes, but for the purpose of this paper, the analysis is concentrated on the seaborne transport of goods.

Table 2 shows perishable foodstuff world trade evolution from 1983 to 2005 resulting in a stable growth rate. That behaviour can be explained by demand for products on regular basis (non-season variations) and increasing population with stable income (indicated by meat group present and forecasted share and exotics as more expensive products, see Tables 4 and 5). The Southern Hemisphere can produce perishable goods during Northern Hemisphere winter, and the fact that Northern Hemisphere has still the largest population (UN, 2011), perishable trade flow is much South-North oriented.

Table 2: World trade in perishable foodstuff (Mt)

\begin{tabular}{|c|c|c|c|c|c|c|c|c|c|c|}
\hline Year & Bananas & Citrus Fruits & Deciduous & Total fruit & Dairy products & Meat & Fish & Total trade & Total & Memo:Other Fruit \& Veg \\
\hline 1983 & 6 & 7 & 5 & 19 & 10 & 9 & 20 & 58 & Growth & 59 \\
\hline 1984 & 7 & 8 & 5 & 20 & 11 & 9 & 22 & 61 & $5,90 \%$ & 63 \\
\hline 1985 & 7 & 7 & 5 & 19 & 12 & 9 & 25 & 64 & $5,10 \%$ & 66 \\
\hline 1986 & 7 & 9 & 5 & 21 & 12 & 10 & 27 & 69 & $7,70 \%$ & 70 \\
\hline 1987 & 8 & 8 & 6 & 21 & 12 & 10 & 28 & 71 & $2,80 \%$ & 73 \\
\hline 1988 & 8 & 8 & 6 & 21 & 13 & 11 & 29 & 74 & $3,50 \%$ & 77 \\
\hline 1989 & 8 & 8 & 6 & 22 & 13 & 11 & 31 & 77 & $4,50 \%$ & 81 \\
\hline 1990 & 9 & 8 & 6 & 24 & 12 & 12 & 29 & 77 & $-0,50 \%$ & 84 \\
\hline 1991 & 10 & 8 & 7 & 25 & 13 & 13 & 29 & 81 & $5,10 \%$ & 88 \\
\hline 1992 & 11 & 9 & 7 & 26 & 15 & 14 & 31 & 85 & $5,40 \%$ & 91 \\
\hline 1993 & 12 & 9 & 8 & 29 & 15 & 14 & 34 & 92 & $7,80 \%$ & 96 \\
\hline 1994 & 13 & 10 & 8 & 31 & 16 & 16 & 41 & 103 & $12,50 \%$ & 102 \\
\hline 1995 & 13 & 10 & 8 & 32 & 16 & 17 & 38 & 103 & $0,00 \%$ & 101 \\
\hline 1996 & 14 & 10 & 9 & 33 & 17 & 18 & 38 & 105 & $1,70 \%$ & 104 \\
\hline 1997 & 15 & 10 & 9 & 34 & 18 & 19 & 39 & 110 & $4,50 \%$ & 107 \\
\hline 1998 & 14 & 11 & 9 & 33 & 18 & 19 & 32 & 104 & $-5,40 \%$ & 109 \\
\hline 1999 & 14 & 10 & 9 & 34 & 19 & 21 & 36 & 110 & $6,10 \%$ & 115 \\
\hline 2000 & 14 & 11 & 9 & 34 & 20 & 22 & 41 & 117 & $6,70 \%$ & 117 \\
\hline 2001 & 15 & 11 & 10 & 35 & 20 & 22 & 41 & 118 & $0,90 \%$ & 123 \\
\hline 2002 & 14 & 12 & 10 & 36 & 20 & 23 & 41 & 120 & $1,80 \%$ & 126 \\
\hline 2003 & 15 & 12 & 11 & 38 & 21 & 24 & 41 & 124 & $3,00 \%$ & 129 \\
\hline 2004 & 16 & 13 & 11 & 40 & 21 & 26 & 41 & 128 & $3,00 \%$ & 131 \\
\hline 2005 & 16 & 14 & 11 & 41 & 21 & 27 & 41 & 130 & $1,40 \%$ & 133 \\
\hline \multicolumn{3}{|c|}{ average (1983-2005): } & & & & & & & $3,80 \%$ & \\
\hline
\end{tabular}

Remark: Includes land and seaborne trades

Source: Authors' elaboration based on Stopford (2009) based and FAO Yearbook and FAO Yearbook of Fishery Statistics

Tables 2 and 3 show the main foodstuff products transported. Cargo seasonality and flows pushed by demand determine how reefer carriers have to operate their fleet, considering not only their risk and return, but also the fact that foodstuff distribution channels are organized on weekly basis. In this regard, the main questions should be: How to operate on weekly basis if the distances between markets are different? How to combine the seasons with the limited capacity increase in the short term? How to get alternative utilization to reefer vessels and reefer 
containers during the off-season periods? All these questions remain still as captivating challenges to specialized carriers.

Table 3: Seaborne transport market share of main reefer commodities 2000-2010

\begin{tabular}{|c|c|c|c|c|c|c|c|c|c|c|c|}
\hline Commodity & 2000 & 2001 & 2002 & 2003 & 2004 & 2005 & 2006 & 2007 & 2008 & 2009 & 2010 \\
\hline Bananas & $20,5 \%$ & $20,1 \%$ & $19,3 \%$ & $19,2 \%$ & $19,0 \%$ & $18,6 \%$ & $18,5 \%$ & $18,1 \%$ & $17,5 \%$ & $17,1 \%$ & $16,9 \%$ \\
\hline Total Citrus & $7,1 \%$ & $6,8 \%$ & $7,1 \%$ & $7,1 \%$ & $7,1 \%$ & $6,8 \%$ & $6,5 \%$ & $6,3 \%$ & $6,3 \%$ & $6,7 \%$ & $6,8 \%$ \\
\hline Total Deciduous & $8,3 \%$ & $8,3 \%$ & $8,4 \%$ & $8,7 \%$ & $8,9 \%$ & $9,1 \%$ & $8,9 \%$ & $9,0 \%$ & $9,0 \%$ & $9,3 \%$ & $9,4 \%$ \\
\hline Total Exotics & $1,9 \%$ & $2,0 \%$ & $2,1 \%$ & $2,2 \%$ & $2,6 \%$ & $2,9 \%$ & $3,1 \%$ & $3,3 \%$ & $3,3 \%$ & $3,5 \%$ & $3,4 \%$ \\
\hline Fish / Seafood & $17,4 \%$ & $18,4 \%$ & $18,2 \%$ & $17,5 \%$ & $18,0 \%$ & $18,1 \%$ & $18,0 \%$ & $18,0 \%$ & $17,1 \%$ & $17,4 \%$ & $17,8 \%$ \\
\hline Total Meat I Poultr & $22,1 \%$ & $21,4 \%$ & $21,9 \%$ & $21,9 \%$ & $21,1 \%$ & $21,6 \%$ & $22,1 \%$ & $22,7 \%$ & $24,5 \%$ & $23,9 \%$ & $24,1 \%$ \\
\hline Total Dairy & $2,0 \%$ & $2,1 \%$ & $2,0 \%$ & $2,1 \%$ & $2,2 \%$ & $2,0 \%$ & $2,1 \%$ & $2,1 \%$ & $2,0 \%$ & $2,1 \%$ & $2,0 \%$ \\
\hline Total others & $20,6 \%$ & $20,9 \%$ & $21,0 \%$ & $21,3 \%$ & $21,2 \%$ & $20,9 \%$ & $20,7 \%$ & $20,5 \%$ & $20,5 \%$ & $20,0 \%$ & $19,6 \%$ \\
\hline grand total & $100,0 \%$ & $100,0 \%$ & $100,0 \%$ & $100,0 \%$ & $100,0 \%$ & $100,0 \%$ & $100,0 \%$ & $100,0 \%$ & $100,0 \%$ & $100,0 \%$ & $100,0 \%$ \\
\hline
\end{tabular}

Source: Authors on elaboration of data based on Drewry Reefer Shipping Market 2010/11 based on FAO database 2005, GTIS from 2006 and Sextant Consultancy

\section{The market}

The reefer market can be described, in this paper approach, by a general market $^{8}$ composition as the product is transport service offered by reefer carriers (conventional and container); the market place is all the ports located in the South American East Coast as a geographical scope determination; the price is sea freight rates by container, as product/service is the transportation from origin to destination and not the vessel charter; finally the way that carriers offer their service to customers, typically exporting goods firms to all possible trades. The classical market characterization can be applied by relevant information: number of players; product homogeneity and of barriers of entry existence.

South American East Coast reefer trades are performed by a limited number of companies in a relatively high concentrated market. The top 15 operators concentrate about $68 \%$ of conventional reefer ships capacity, and top 25 companies concentrate $85 \%$ of reefer containers. (Dynamar, Sep 2010)

The product/service (transport) can be considered in general as homogeneous; transport services from $A$ to $B$, but each company may offer some kind of differential on trade as transit time, vessel type, logistics services, etc. Nevertheless, products/services offered by reefer container carriers cannot be easily replaced by the conventional reefer carriers. Actually, in many cases, the containerization process is a one-way road as reverting the process implies in major additional operational costs.

A clear barrier of market entry is the expressive capital requirement, not only for setting up the service (vessel charters and/or leasing of reefer boxes), but also service management capability, as specialized knowledge is required to combine reefer cargo seasons as well as equipment typology and adequate transit times to products shelf life. For reefer market characterization, Stopford (2009) commented that: "Perhaps the most interesting aspect of the refrigerated cargo trade from the maritime economics viewpoint is the competition between different transport modes of type of cargo". (Stopford, 2009, p. 491)

Porter (2008) proposed an industry characterization model with five interrelated forces. Porter's five forces' model applied to the seaborne reefer market in South American region could result:

1. New entrants' threat is relatively low due to strong entry barriers;

2. Practically, there is no substitute to reefer cargo sea transport, mainly due to its large volumes 
and suppliers ${ }^{9}$, power over the reefer carriers can be neutralized;

3. In buyers' side, an increasing growth in their bargain power resulting from an expressive concentration process via mergers and acquisitions' operations can be identified.

4. There is a remarkable concurrence between carriers, and the rivalry is aggressive and permanent.

In other words, the reefer carriers' profitability will depend on their interrelationship, as their reduced number could result in a high interdependence in their pricing policies. This was for sure a very brief application of theoretical competitive analysis to reefer cargo. The market complexity can certainly be approached by other theories that could supplement or even replace the analysis. This, surely, can be a theme for further studies and researches and the theme, regardless of its importance, was considered by authors as being beyond this paper focus.

\section{South American East Coast Reefer Cargo: Market Particularities}

The South American East Coast reefer market can be divided in two main areas: Brazilian Coast and River Plate ports. Traditionally due to its exporting vocation of basic agricultural products, the three countries Brazil, Uruguay and Argentina are by default reefer market traditional players. Dynamar (2010) reports these countries' relevance in South America as a whole, as follows:

"With exports in 2007 exceeding 24 million tons, countries in South America are a major driver behind seaborne reefer trade. In particular, Brazil, Ecuador and Chile and to a lesser extent Argentina and Colombia sell sizeable quantities of produce. With more than 8 million tons, meat is the biggest category, mainly poultry (3.7 million tons) and bovine meat (3.0 million tons). Brazil is responsible for more than three quarters of this total; Argentina follows with a share of 8\%." (Dynamar, 2010, p. 37)

The analysis is divided in five sub-sections as follows: (1) Cargo flows; (2) Ports infrastructure; (3) Post-panamax vessels' operation and respective economies of scale; (4) Shippers and carriers' mergers and acquisitions' processes and (5) Containerization process. The analysis was supported by interviews with reefer senior managers active in the Brazilian and Plate area reefer markets. The specialists interviewed were: Mr. Henrik Simon senior reefer director at Hamburg Süd; Roberto Aschenberger - former reefer manager of Maersk Sealand at Salvador; Rogerio Meneghetti - sales reefer manager at Samskip (Freight Forwarder); Santiago Rigby - senior Sales manager at Hamburg Süd Uruguay and Americo Veiga - owner of Navitradeship (Reefer broker based in São Paulo and with activities in the main reefer markets in South America). The interviews took place during April and May 2011, and were performed per phone, e-mail and complemented with direct contact with the market experts.

\section{The cargo flow}

The cargo flow analysed presents two basic aspects: first, the imbalance between outbound (exports) and inbound (imports) cargoes. As previously stated, the South American East coast is typically a refrigerated goods exporting area. Therefore, reefer import trades are much smaller in absolute as well as in relative terms, as shown in Table 4. Over the past six years (from 2007 to 2013), reefer imports are growing, as a consequence of the macroeconomic situation (pushed by Brazilian internal market and US Dollar exchange rate to Brazilian Reais and Argentinean Pesos), but it is still a much smaller market than exports. This imbalance leads reefer carriers to an unpleasant situation, lack of return cargo for reefer ships and/or reefer containers. This adds costs which impact shipping liners' pricing policy. ${ }^{10}$ 
Table 4: South American East Coast Exports vs. Imports (in TEUs)

\begin{tabular}{|c|c|c|c|c|c|c|c|}
\hline \multicolumn{8}{|c|}{ All Carriers, all trades (2013 data until July $30^{\mathrm{hn}}$ only) } \\
\hline & 2007 & 2008 & 2009 & 2010 & 2011 & 2012 & $2013^{*}$ \\
\hline Export (outbound) & 715.919 & 735.054 & 740.831 & 730.363 & 725.588 & 736.914 & 493.573 \\
\hline Import (inbound) & 39.437 & 50.110 & 63.126 & 72.108 & 90.400 & 99.686 & 59.736 \\
\hline Ratio Exp/Imp & 18,2 & 14,7 & 11,7 & 10,1 & 8,4 & 7,4 & 8,3 \\
\hline equivalent per week 40rh & 7.263 & 7.550 & 7.730 & 7.716 & 7.846 & 8.044 & 9.222 \\
\hline
\end{tabular}

Source: Authors elaboration based on Dataliner/Centronave (2012)

When analysing the reefer trades of exports' volumes, it is remarkable how the Middle East and West Africa have increased their share (almost doubled) in the overall trade in a relatively short period (from 2006 to 2012). At the same time, European trades have lost position, as shown in Table 5. This fact can be explained by the increasing Brazilian share in foodstuff supply to countries like Saudi Arabia, Iran, Venezuela, Egypt, and, of course, China.

Table 5: South American East Coast reefer container share (in \% of TEUs)

\begin{tabular}{|l|ccccccc|}
\hline Trade & $\mathbf{2 0 0 6}$ & $\mathbf{2 0 0 7}$ & $\mathbf{2 0 0 8}$ & $\mathbf{2 0 0 9}$ & $\mathbf{2 0 1 0}$ & $\mathbf{2 0 1 1}$ & $\mathbf{2 0 1 2}$ \\
\hline North Europe \& Russia & $36,40 \%$ & $37,80 \%$ & $36,40 \%$ & $32,80 \%$ & $30,20 \%$ & $28,38 \%$ & $28,1 \%$ \\
Asia & $17,60 \%$ & $17,40 \%$ & $18,90 \%$ & $19,70 \%$ & $19,50 \%$ & $22,11 \%$ & $22,2 \%$ \\
Middle East & $9,60 \%$ & $10,90 \%$ & $13,20 \%$ & $17,20 \%$ & $18,60 \%$ & $18,36 \%$ & $17,4 \%$ \\
East Mediterranean & $11,60 \%$ & $9,10 \%$ & $8,10 \%$ & $8,20 \%$ & $8,10 \%$ & $7,47 \%$ & $9,6 \%$ \\
Gulf \& Caribbean Island & $4,80 \%$ & $5,70 \%$ & $7,40 \%$ & $5,10 \%$ & $5,50 \%$ & $6,30 \%$ & $5,5 \%$ \\
West Mediterranean & $7,20 \%$ & $7,50 \%$ & $5,80 \%$ & $6,00 \%$ & $6,60 \%$ & $5,20 \%$ & $4,6 \%$ \\
West Africa & $2,70 \%$ & $3,10 \%$ & $3,50 \%$ & $4,30 \%$ & $4,40 \%$ & $5,10 \%$ & $5,6 \%$ \\
East Coast North America & $5,10 \%$ & $4,20 \%$ & $2,90 \%$ & $2,70 \%$ & $2,60 \%$ & $2,80 \%$ & $2,5 \%$ \\
South Africa & $3,30 \%$ & $2,60 \%$ & $2,10 \%$ & $2,40 \%$ & $2,60 \%$ & $2,70 \%$ & $2,8 \%$ \\
Mercosul & $0,80 \%$ & $0,70 \%$ & $0,60 \%$ & $0,90 \%$ & $1,20 \%$ & $0,70 \%$ & $0,9 \%$ \\
West Coast South America & $0,60 \%$ & $0,50 \%$ & $0,40 \%$ & $0,40 \%$ & $0,60 \%$ & $0,50 \%$ & $0,7 \%$ \\
Others & $0,40 \%$ & $0,50 \%$ & $0,60 \%$ & $0,30 \%$ & $0,20 \%$ & $0,30 \%$ & $0,3 \%$ \\
\hline Total & $100,00 \%$ & $100,00 \%$ & $100,00 \%$ & $100,00 \%$ & $100,00 \%$ & $100,00 \%$ & $100,0 \%$ \\
\hline
\end{tabular}

Source: Authors own elaboration based on Dataliner/Centronave (2011)

Table 6: Commodity share at South American East Coast ports (all in TEUs, export only)

\begin{tabular}{|l|ccccccc|}
\hline Commodities (by group) & $\mathbf{2 0 0 6}$ & $\mathbf{2 0 0 7}$ & $\mathbf{2 0 0 8}$ & $\mathbf{2 0 0 9}$ & $\mathbf{2 0 1 0}$ & $\mathbf{2 0 1 1}$ & $\mathbf{2 0 1 2}$ \\
\hline Meat Poultry & $27,6 \%$ & $29,6 \%$ & $36,2 \%$ & $36,0 \%$ & $40,1 \%$ & $41,9 \%$ & $42,2 \%$ \\
Fruits, veg. \& flowers & $19,1 \%$ & $22,4 \%$ & $21,8 \%$ & $18,0 \%$ & $19,0 \%$ & $18,2 \%$ & $16,4 \%$ \\
Meat Bovine & $23,9 \%$ & $21,2 \%$ & $15,8 \%$ & $17,7 \%$ & $15,3 \%$ & $13,3 \%$ & $14,1 \%$ \\
Meat Pork \& Offal & $12,0 \%$ & $12,0 \%$ & $12,5 \%$ & $13,4 \%$ & $12,8 \%$ & $12,9 \%$ & $13,1 \%$ \\
Fish and crustaceans & $7,8 \%$ & $6,3 \%$ & $6,1 \%$ & $5,5 \%$ & $5,1 \%$ & $5,7 \%$ & $5,8 \%$ \\
Fruit juice & $3,2 \%$ & $3,0 \%$ & $2,8 \%$ & $2,9 \%$ & $2,7 \%$ & $2,7 \%$ & $2,8 \%$ \\
Food / Beverage & $2,3 \%$ & $2,0 \%$ & $2,7 \%$ & $2,4 \%$ & $2,5 \%$ & $2,5 \%$ & $2,6 \%$ \\
Others & $4,0 \%$ & $3,5 \%$ & $2,2 \%$ & $4,0 \%$ & $2,7 \%$ & $2,7 \%$ & $2,9 \%$ \\
\hline Total geral & $100,0 \%$ & $100,0 \%$ & $100,0 \%$ & $100,0 \%$ & $100,0 \%$ & $100,0 \%$ & $100,0 \%$ \\
\hline Share of meat group & $71,3 \%$ & $69,1 \%$ & $70,6 \%$ & $72,6 \%$ & $73,3 \%$ & $73,8 \%$ & $75,2 \%$ \\
\hline
\end{tabular}

Source: Authors own elaboration based on Dataliner/Centronave (2011)

The fresh fruits' share can vary from year to year depending on seasonal factors, like weather and competition with other growing areas (apples from Chile or citrus from South Africa coming at the same time onto European trades). The other commodity groups have more or less stable share and development over the years. The overview on these database calls attention on the increasing concentration of meat group over the period 2006-2012. 


\section{Ports Infrastructure}

There is certainly more than one way to analyse ports' infrastructure. The data available for the reefer cargo per loading port is rare and time series were not found to identifying the evolution of ports' capacity for reefer cargo. Table 7 demonstrates container terminals' predominance over conventional reefer ships' terminals. Also, relevant is the official draft informed by ports' authorities: with few exceptions, ports' vast majority presents an average draft of 10 to $11 \mathrm{~m}$, which limits the operation of vessel with larger capacity like the Post-Panamax.

The information collected from the main terminal operators (as per Table 8) give a better main reefer cargo load ports' overview. Nevertheless, South American East Coast ports do not look like the same, but they present infrastructure and operation capital resemblance with a few exceptions ${ }^{11}$. The main ports are still the same established in colonial times, located inside city areas and therefore with limited capacity of expansion or renovation.

Table 7: South American East Coast reefer cargo load main ports - 2006-2010 (in TEUs)

\begin{tabular}{|c|c|c|c|c|c|}
\hline Port of Load & 2006 & 2007 & 2008 & 2009 & 2010 \\
\hline Itajai /Sao Francisco do Sul & 148.825 & 153.172 & 158.262 & 132.554 & 152.025 \\
\hline Paranagua & 56.885 & 87.618 & 107.175 & 136.622 & 136.445 \\
\hline Santos & 126.667 & 141.871 & 133.675 & 125.629 & 128.069 \\
\hline Rio Grande & 43.581 & 52.002 & 57.507 & 61.237 & 57.572 \\
\hline Fortaleza/Mucuripe & 30.175 & 40.589 & 39.831 & 32.870 & 32.629 \\
\hline Salvador & 12.387 & 12.427 & 12.649 & 8.531 & 9.266 \\
\hline Natal & 2.134 & 2.627 & 4.736 & 4.988 & 5.778 \\
\hline Rio de Janeiro / Sepetiba & 5.212 & 6.404 & 5.177 & 4.252 & 4.711 \\
\hline Recife / Suape & 6.161 & 2.876 & 6.480 & 8.266 & 4.394 \\
\hline Belem / Vila do Conde & 1.516 & 1.613 & 1.729 & 2.457 & 3.618 \\
\hline Vitoria & 976 & 645 & 536 & 694 & 638 \\
\hline Manaus & 69 & 418 & 612 & 432 & 227 \\
\hline Imbituba & 1.227 & 315 & 522 & 337 & 28 \\
\hline Navegantes & 0 & 3.932 & n.a. & n.a. & n.a. \\
\hline Sub-total Brazil & 435.875 & $502.578^{\prime}$ & 528.892 & 518.868 & 535.398 \\
\hline Buenos Aires & 108.550 & 114.457 & 108.361 & 113.418 & 101.285 \\
\hline Montevideo & 77.786 & 90.351 & 47.532 & 63.385 & 50.148 \\
\hline San Antonio De Este & 94 & 14 & 11.762 & 7.918 & 9.952 \\
\hline Zarate & n.a. & n.a. & 1.124 & 6.494 & 6.666 \\
\hline Mar del Plata & 2.941 & 1.551 & 8.787 & 8.249 & 6.266 \\
\hline Asuncion & n.a. & n.a. & 3.460 & 4.549 & 5.129 \\
\hline Puerto Madryn & 1.715 & 1.441 & 5.618 & 5.860 & 4.896 \\
\hline Puerto Deseado & 1.702 & 1.488 & 5.628 & 4.717 & 2.938 \\
\hline Rosario & n.a. & n.a. & 6.235 & 2.032 & 1.158 \\
\hline Ushuaia & 669 & 93 & 1.879 & 1.827 & 1.012 \\
\hline Baia Blanca & 14 & 14 & 5.777 & 3.514 & 960 \\
\hline sub-total Plate & 193.471 & 209.409 & 206.162 & 227.963 & 190.410 \\
\hline Grand total (Brazil \& Plate) & 629.286 & 711.988 & 735.054 & 740.831 & 725.809 \\
\hline Share of Brazilian ports & $69,3 \%$ & $70,6 \%$ & $72,0 \%$ & $70,0 \%$ & $73,8 \%$ \\
\hline
\end{tabular}

Remarks: n.a.: data not available

Source: Authors' elaboration based on Dataliner/Centronave (2010) 
Table 8: South American East Coast main ports reefer plugs capacity
(in December 2010, not including pre-stacking hinterland area)

\begin{tabular}{|l|c|}
\hline \multicolumn{1}{|c|}{ Port - Terminal } & $\begin{array}{c}\text { Reefer plugs (in units of } \\
\text { sockets) for 20' or 40' reefer } \\
\text { containers }\end{array}$ \\
\hline Buenos Aires (Argentina: BACTSSA (T5) / & 2.300 \\
EXOLGAN / APM TERMINAL -T4) & 3.300 \\
Montevideo (Uruguay) - Montecon and TCP & 1.750 \\
Rio Grande (Brazil) - Tecon & 1.400 \\
Itajai (Brazil) - Teconvi & 1.200 \\
Navegantes (Brazil) - Portonave & 510 \\
São Francisco do Sul (Brazil) - TESC & 2.450 \\
Paranagua (Brazil) - TCP & 3.500 \\
Santos (Brazil) - SBSA / LIBRA / Rodrimar & 270 \\
Rio de Janeiro (Brazil) - Libra & 400 \\
Sepetiba (Brazil) - Tecon & 70 \\
Vitoria (Brazil) - TVV & 550 \\
Salvador (Brazil) - Tecon & 300 \\
Suape (Brazil) - Tecon & 200 \\
Natal (Brazil) - Codern & 200 \\
Mucuripe/Fortaleza (Brazil) - Docas do Ceara & 890 \\
Pecem (Brazil) - CTO & Not available \\
Belem / Vila do Conde (Brazil) & Not available \\
Manaus (Brazil) & 19.290 \\
\hline total &
\end{tabular}

Source: Authors own elaboration based on Port terminal operators information

In general, ports and mainly terminal operators have improved their capacity and structure to meet reefer cargo in containers' requirements. This is clear by crossing the information given on Table 4 and Table 8 (with the equivalent 40rh boxes per week reaching 9,222 in 2012 against a plug capacity of 19,290 in 2010). However, these ports' problems affecting reefer cargo are not exclusively related to perishable products' characteristics, but also to several bottlenecks linked to public ports' policy reflected in accesses from land and by water (dredging still limited to geographical conditions) and terminals' capacity (considering the fast international trade increase versus lead time to build and operate new port areas) improvement requirements.

\section{Post-panamax vessels' operation and respective economies of scale}

As mentioned before, carriers all over the world have increased the relation of reefer plugs per TEU in new bigger vessels, as a consequence of reefer cargo containerization. This is a global trend; as South America is one of the main reefer areas, the size of vessels calling the region has also increased. Figure 7 shows an interesting chart of ships capacities' evolution over the last few decades presented by Hamburg Süd, one of the market leaders in the South American East Coast trades.

It is clear that carriers are looking for operational optimization and economies of scale provided by bigger ships, and take advantage of the profitability of reefer cargo share as part of the cargo mix. In this regard, Mr. Simon (Hamburg Süd Reefer department Director) interviewed, said:

"The shipping line of course benefits from economies of scale, as with larger capacity we need fewer ships for the same weekly services, but the reefer slot is an expensive investment for carriers, as the power consumption on board increases and also the risk exposure of transporting more perishable cargo on the same vessel." 
Table 9: Hamburg Süd capacity increase by vessels categories. Source: the Authors based on Costa (2011).

\begin{tabular}{|l|c|c|c|c|c|}
\hline \multicolumn{1}{|c|}{ Class } & Year & $\begin{array}{c}\text { Reefer } \\
\text { Plugs } \\
\text { (TEU) }\end{array}$ & $\begin{array}{c}\text { Plugs } \\
\text { Growth } \\
\text { from } \\
\text { previous } \\
\text { category }\end{array}$ & $\begin{array}{c}\text { Nominal } \\
\text { Capacity } \\
\text { (TEU) }\end{array}$ & $\begin{array}{c}\text { TEU growth } \\
\text { from previous } \\
\text { category } \\
\text { Capacit }\end{array}$ \\
\hline $\begin{array}{l}\text { Cap San / } \\
\text { Bahia }\end{array}$ & $2001 / 2007$ & 800 & -- & 3700 & -- \\
\hline Monte / Rio & $2004 / 2009$ & 1365 & $70,6 \%$ & $5500 / 5900$ & $48,6 \% / 59,5 \%$ \\
\hline Santa & $2010 / 2012$ & 1600 & $17,2 \%$ & 7100 & $20,3 \%$ \\
\hline $\begin{array}{l}\text { Cap San } \\
\text { forecast) }\end{array}$ & $2013 / 2014$ & 2100 & $31,3 \%$ & 9600 & $35,2 \%$ \\
\hline
\end{tabular}

Nevertheless, these economies of scale have not being reflected as lower freight rate as stated by Veiga (Navitradeship owner) in an interview:

"In South America, I do not think that freight can reduce through the use of larger vessels with economies of scale. Here in Brazil, Argentina, and Uruguay and also in South American West Coast what really counts is the old law of supply and demand (for space)."

Potentially, rates' cuts could be resulted from Freight Forwarders' actions regarding their traditional consolidating volumes' approach for bargaining volumes and prices. But, this also, as it was identified in the interviews, did not take place (until nowadays, at least). Freight Forwarder participation in reefer business is still low if compared with direct freight market by shippers $(3.0 \%$ in 2010$)$.

\section{Shippers and carriers' mergers and acquisitions processes}

Another interesting phenomenon in South American reefer market is the remarkable concentration process both at shippers' and carriers' sides. Statistic data gathered demonstrate that at both sides shippers (demand) and carriers (supply) have consolidated their operation in several mergers' and acquisition processes.

In the carriers' side, two aspects are relevant: first, the increase in global container operators' static capacity from 435,000 TEUs in 1980 to 12.9 million of TEUs in 2011, only considering the top 20 container operators worldwide. Second, the top 5 carriers increased concentration, from $44 \%$ in 1980 to $52 \%$ in 2011 . Specifically in the case of reefer container carriers, one can notice that since 2006 the market has been very concentrated, as the top 5 carriers dominated more than $80 \%$ of reefer loadings ${ }^{12}$.

In the shippers' side, the situation does not change much as the top five shippers went from a concentration of $28.5 \%$ in 2006 to $45.6 \%$ in 2010 . There are many factors that could explain the increasing mergers' and acquisition processes in Brazil, Argentina and Uruguay and they can be summarized in two typical situations: Small companies, normally owned by families, lost their scale to larger ones, which could practice more competitive prices (like what happened in the fresh fruit $^{13}$ and frozen juice business ${ }^{14}$ ); or the companies that have suffered cash flows' problems during the financial crises in 2008/2009 (like what happened very 
though to the bovine meat and poultry exporters) ${ }^{15}$.

On this regard, Mr Simon said that:

"Yes, I believe this process is ended, at least slowed down and, on the contrary, there might be a trend of re-selling (splitting) these companies merged in the last 10 years, as the buyers prefer to have alternative suppliers instead of one or two very large companies (like in the poultry business). For carriers the impact was huge, as in the past we used to have 10 different shippers in certain market and we could decide the best combination for each shipper volume. Nowadays, we have three or four to make business. This represents a dependence increase for both sides: shippers and carriers. It is still unclear how positive this change could be."

Aschenberger (former Maersk Sealand reefer manager) pointed in his interview:

"The market is dynamic. There will always be mergers and acquisitions. However, due to globalization and its increased competitiveness, there is a pressure for reducing costs to remain profitable. In this situation, the companies' concentration results to be critical. With larger volumes in less exporting firms hands (due to concentration), it has been a great pressure for reducing freight costs."

As early mentioned, the migration of cargo from traditional full reefer vessels to the reefer container is a global trend. According to Mr. Simon:

"There still a lot be containerized mainly in the Plate area (Argentina). Fruits (like apples and pear ex Patagonia ${ }^{16}$ and Citrus at Up River ${ }^{17}$ areas) are still at 50/50 proportion. And there are also a lot of fish from Falkland Islands, which is still loaded in conventional reefer ships."

The containerization process certainly requires a more detailed investigation which is not the case here, but it is important to consider as phenomena still taking place in the South American east coast trades.

\section{Conclusion}

This paper's first important conclusion is that reefer cargo has several trades, flows and transportation requirements, which characterise it as a very specific market niche operated by specialists. The risk of transporting reefer goods is much larger than the general cargo, and therefore shipping liners involved have to be more dedicated and specialized, resulting in a more concentrated market.

As it was previously quoted, oligopoly market operation could be summarized as follows: (1) Reduced number of players; (2) clear barriers of entry; (3) low probability of substitutive services/products in the short term and (4) uncertain and interdependence among agents regarding their pricing policies.

As, especially in Brazil, the containerization process is coming to its end, carriers' efforts are concentrated in their strategic share in the reefer container business. As it was demonstrated, South American reefer market has passed by an important concentration process, leading carriers and shippers to different and more balanced bargain power in their operations.

It is possible to preview that South American perishable goods' trade will keep growing in the coming years, especially considering that Brazil has still a lot to grow in as global player in the foodstuff market ${ }^{18}$, and Argentina has still a significant volume of reefer cargo to containerize in Patagonia and Up River areas. On the other hand, it would be skittish just to say that it will happen in three or five years, as perishable trade market depends very much on economic factors affecting foodstuff international trade and on local infrastructure to support export trade volumes.

This paper aimed to analyze this important niche in maritime freight market, focusing on reefer traffic in the South American East Coast. It was possible to conclude that the industry, both sides (shippers and carriers) showed relevant and recent concentration processes. Therefore, from an academic 
point of view it has accomplished its explanatory purpose on reefer market at the South American East Coast, but is far from exhausting research possibilities in this specialized and demanding niche market.

\section{Acknowledgements}

The authors are grateful to business experts Henrik Simon, Roberto Aschenberger, Americo Veiga, Santiago Rigby, Rogerio Meneghetti for their prompt assistance and cooperation in gathering information and market expertise support for the paper development.

\section{Notes}

${ }^{1}$ Refers to statistic data available on ABEF (2012).

${ }^{2}$ Additional information on poultry exports volumes: In 2011, according to Dataliner/Centronave, Brazil Foods has exported 90,000 FEUS, which represents an average of almost 2,000 FEUS per week for more than 130 different countries.

${ }^{3}$ Southern region of Argentina. Statistic data retrieved from Patagonia Norte (2011).

${ }^{4}$ The cooling down a product main purpose is to avoid four kind of deterioration: First, external physical deterioration which can start by other factors (like inadequate packaging), but worsen, oscillation of temperature. Second, physiological deterioration, which is defined as damage in product functionalities (like mangoes under too low temperature and are injured by chill). Third, chemical deterioration caused by product substances reaction or other used for its conservation. Fourth, the pathological deterioration caused by diseases organisms (fungi and bacteria) that can more easily develop at higher temperatures. (MMS, 2006)

5Typical reefer cargo claims on the carrier are: 1. Temperature deviations (high carriage temperature; chilling; freezing). 2. Humidity and atmosphere management. 3. Service: delay on transit time. 4 . Reefer bad functioning. 5. Poor container hygiene, poor container condition (structure). 6 . Others: pre-shipment conditions: post harvest, pre-cooling, packaging, stowage (air circulation). MMS - Marine Management Surveyors UK (2006):

${ }^{6}$ Levinson (2006) describes containers usage by the US Army and Navy during 1960 s and 1970 s.

${ }^{7} \mathrm{~A}$ liner service can be defined as a regular service with fixed schedules and pre announced transit times between call ports. (Malchow and Schultze, 1993)

${ }^{8}$ Guerise (2006) supported by Ballou (1993); Bowersox et al. (2002); Robles (2001).

${ }^{9}$ Typical suppliers, local companies such as: terminal operators; stevedores; tug boat companies and reefer cold stores.

${ }^{10} \mathrm{An}$ alternative taken by carriers to reduce this imbalance is reefer containers offer to importers as dry box moving as "NOR" (non-operating reefer). But this is not count as part of reefer import trade.

11Exception in this case are Rio Grande at Rio Grande do Sul (Brazilian Southern Region), Pecem that is $60 \mathrm{~km}$ away from Fortaleza (Brazil) and Suape that is $50 \mathrm{~km}$ away from Recife (Brazilian Northeastern Region).

12For a detailed analysis about mergers and acquisitions, see Galvão (2009a, 2009b)

13Univeg group is one example, as they have purchased over 20 different farms.

${ }^{14}$ Citrovita purchase by Votorantin Group is another good example.

${ }^{15}$ The cases of Sadia taking over by Perdigão (lately named as Brazil Foods) and the Frigorifico Bertin taken by JBS/Friboi group are also illustrative cases.

${ }^{16}$ Cargo loaded in Baia Blanca and San Antonio de Este in Argentina.

${ }^{17}$ Cargo loaded in Zarate Port in Argentina. 
${ }^{18}$ For example, Brazil is not participating in the fresh banana trades, one of the international reefer business main commodities.

\section{References}

1. ABEF. [On line], [Retrieved January 15, 2012],

http://www.abef.com.br/ubabef/exibenoti ciaubabef.php?notcodigo $=2761$.

2. Ballou, R.H. (1993), Logística Empresarial: Transportes, Administração de Materiais e Distribuição Física, Atlas, São Paulo.

3. Bowersox, D.J., Closs, D.J., \& Cooper, M.B. (2002). Supply Chain Logistics Management, McGraw Hill Higher Education, New York.

4. Business Dictionary. (2011). [On line], [Retrieved March 3, 2011], http://www.businessdictionary.com/

5. Dataliner, Centronave Data Bank. (2012/2011/2010). [On line], [Retrieved Februrary 7, 2012], http://www.datamar.com.br/DataLiner.as px 2012

6. Costa, G. (2011), 'Modalidades de Transporte na Movimentação de Contêineres', Conference at $8^{\text {th }}$ Seminário Internacional em Logística Agroindustrial on April 18, 2011 in ESALQ-LOG, Piracicaba (SP), [On line], [Retrieved April 20, 2011], http://log.esalq.usp.br/home/pt/seminari o.php?sh=2011_2

7. De Haan, H. (2005), De Beer's consolidated manual on the transportation of perishable cargo in reefer containers, BTM De Beer b.v., Rotterdam.

8. Drewry (2010), Reefer Shipping Market 2010/11, Drewry Shipping Consultants, London.

9. Dynamar (2010). Reefer Analysis: Market Structure Conventional Containers. Dynamar Bv., September, 2010.
10.Galvão, C. B. (2009a), os portos marítimos na mundialização do capital. MSc. Thesis in Economics, Pontifícia Universidade Católica de São Paulo (PUC/SP).

11. (2009b). Fusões e Aquisições: uma outra forma com a mesma essência. In: Marques, R.M. O Brasil sob Nova Ordem. São Paulo: Saraiva.

12.Guerise, L. C. (2006). Aplicação dos conceitos de logística integrada na exportação de açúcar e suco de laranja pelo Porto de Santos. 148p. MSc thesis in Business Management, Universidade Católica de Santos, Santos-SP.

13.Maersk Line (2006), The Reefer Seminar on South America Reefer Operations department, São Paulo.

14.Malchow, G. and Schultze, D. (1993), Güterverkehr über See. Lüneburg: SternVerlag KG.

15.MMS (2006), Marine Management Surveys. Reefer Seminar. São Paulo.

16.Patagonia Norte (2011), Estadística de Embarque. [On line], [Retrieved March 23, 2012], http://www.patagonianorte.com.ar/estadisticas.htm.

17.Robles, L.T. (2001), A prestação de serviços de logística integrada na indústria automotiva no Brasil: em busca de alianças estratégicas logísticas, PhD Thesis in Business Administration, Faculdade de Economia, Administração e Contabilidade da Universidade de São Paulo, FEA-USP, São Paulo.

18.Stopford, M. (2009), Maritime Economics, Routledge, Taylor \& Francis Group, $3^{\text {rd }}$ Ed., New York.

19.UN. (2011), United Nations, World Basic Data, [On line], [Retrieved March 20, 2011], http://www.un.org/esa/population

20.Waals, F. (2010), Dynamar 2010, Reefer Analysis - Market Structure, Conventional, Containers. Alkmaar: Dynamar B.V. 